Article

\title{
'Smell Your Sheep, Shepherd': What Does It Mean to Be Catholic for the Dalit?
}

\section{Rowena Robinson}

Department of Humanities and Social Sciences, IIT Bombay, Mumbai 400076, India; rowena@iitb.ac.in

Received: 30 September 2019; Accepted: 2 December 2019; Published: 4 December 2019

\begin{abstract}
The anthropology of Christianity has emerged as an exciting field in the last decade or so. Themes of interest for us in India and South Asia in general include issues of caste, conversion and belief, the ideas of sin and morality, individualism, and the like. As part of this growing field, the issue of belief in particular has gained considerable importance. It has been argued that the strict reliance on belief is obstructive and counterproductive for the understanding of non-Western Christianity, particularly where religious affiliations may be shifting rather than stable. Moreover, it has been suggested that belief could be laid aside in favor of the notion of commitment, wherein the latter term encompasses presence, embodiment, shared social location, and the like. This paper argues that while the discourse oscillates between belief on the one hand and commitment on the other, the intermediating term between these might be community. There are social and spiritual divisions, which the available discourse does not immediately allow us to contend with. In the words of one Dalit Catholic, the church must be with its people, the Bishop-Shepherd must 'smell' his sheep. This paper will explore how it is precisely the absence of community that Dalit Catholics experience when they find that Christian equality becomes physical separation and Christian fraternity remains outside the social domain and will suggest the implications this has for the anthropology of Christianity.
\end{abstract}

Keywords: Dalits; Tamil Nadu; community; belief

\section{Introduction}

During fieldwork in Tamil Nadu, Dalit Jesuit Fr Yesumarian said to me that the church must be with its people, the Bishop-Shepherd must 'smell' his sheep. For a person in a caste-based society, caste-belonging means sharing biological substance with all its implications of the mingling and enmeshing of bodily fluids and blood, the commonality and merging of touch, tastes, and smells. This in turn produces particular forms of character and conduct, values, and shared beliefs (see, for instance, Béteille 1990, p. 494). Untouchability characterized relationships with the Dalit in caste Hinduism. Their conversion to Christianity often in mass movements in south India must be seen as an effort to shift decisively away from the denigration and stigmatization of caste (see, for instance, Oddie 1977) towards a religion that promises equality to the community of believers. However, conversion did not achieve the hoped-for effects; caste continued to manifest itself both in the church and outside of it. For Fr Yesumarian and other Dalit Catholics, these forms of separation are experienced as particularly galling. Theirs is a call for the full realization of community among Tamil Christians, a claim that allows us to rethink the shift in the recent anthropology of Christianity from a focus on belief on the one hand (Robbins 2007) to commitment (Howell 2007) on the other.

The paper argues that a spectral concept remains concealed and unacknowledged beneath this scholarly debate and the move it seeks to accomplish. That concept is community, upon which is predicated the turn from belief to commitment in Howell's work (Howell 2007). Commitment does not appear problematic when there is an actual community—of relationships and shared practical activities and social involvements-on which it is grounded. However, what happens when the social space of 
community is saturated by caste, as among the Tamil Catholics? By uncovering the key mediating term of community in the reconfiguration of belief as commitment, this paper is able to ask what commitment might look like in its absence or when the two split apart. In particular, when the social boundary of caste as community chafes against commitment to Christian fellowship and fraternity, Dalit Christians experience and express a seething discontent.

A reexamination of the terms of the above debate also allows this paper to throw critical light on the contrast drawn in the literature by Joel Robbins (Robbins 2003, 2007, 2014) between 'old' and 'new' anthropologies of Christianity.

In sum, the new anthropology of Christianity inter alia asks such questions as what difference Christianity makes, what is novel about being Christian, who can be called Christian, and who is absolutely not be counted as such (see also Cannell 2005 and Jenkins 2012). On the other hand, the 'old' anthropology of Christianity by implication and explicit assessment is considered merely ethnographic and, indeed, so partial to the idea of continuity that it tended to 'analyze away the Christianity' of those studied and to suggest that it was merely a veneer adopted perhaps for political or pecuniary reasons. It stressed continuities and stabilities in contrast to the new anthropology.

Anything written before 2000 belongs essentially to the 'prehistory' of the field. This argument places the work of most Indian scholars of Christianity in the domain of prehistory and the merely ethnographic.

While the stress on discontinuities is hardly difficult to accept, one needs to acknowledge that differences emerge when Christianity is not the dominant religion or the only minority religion but is just one among many available religious sensibilities in a complex, highly diversified, and plural society. Moreover, in such societies, Christianity may have come in many forms and denominations and at different periods of time. It is necessary to take into account the specific historical juncture at which Christianity established itself and the ways in which it did so. Indeed, it may turn out that baptism either precedes conversion or follows it: seeing the two as synchronous and constructing conversion thereby as marking a categorical rupture of past from present through this ritual is problematic. It closes one off from exploration of the long struggles with conversion, often after baptism, and how these engage ordinary persons, clergy, and others in what is manifestly less an event than a process. Certainly, many studies in India have shown that there were differences between the societal incorporation of Christianity that came before British rule and that which came to Indian shores thereafter. The earlier phase saw a great deal of continuity with the prevalent social order and norms. It is in the later phase that mass movements, particularly of Dalits seeking to shrug off the societal burden and humiliations of caste, were prominent and there were efforts to sever more sharply the past from the present.

Certainly, the Dalits in this paper are present-generation inheritors of those struggles. However, they are faced with a set of concerns that are quite different and perhaps even contrary to those addressed in the new anthropology of Christianity. These arise not from their reluctance to shed their past or from the fact that they are really 'Hindus' beneath a veneer of Christianity, but from something else. One may return to Robbins' (Robbins 2007, p. 14) distinction between belief 'in' and belief 'that'. He associates belief 'in' something —in God for instance or some value or moral idea-with trust in and commitment to 'act in certain way' towards the object of one's belief or because of that belief. This sense of the verb 'to believe' conveys both a 'certainty and conviction about what one is saying and about the rightness of the actions one's speech is explaining or justifying' (Robbins 2007, p. 14). On the other hand, one has the other sense of belief in the phrase 'to believe that'. This in contrast communicates a sense of uncertainty, as opposed to the phrase 'to know that' and it is applied to 'propositional statements', which one might add are approached intellectually rather than through interior revelation or any process other than that of pure rational comparison.

The argument is that the 'believe in' concept may be more universally applicable; the 'believe that' being particularly characteristic of modernity. Thus, to think of other cultures via the 'believe that' model lends itself to continuity thinking. Since most cultures do not eliminate older propositions even as new ones emerge, it is easy to suggest that no radical change has occurred and past logics continue 
to persist. On the other hand, Robbins offers (Robbins 2007, p. 15), were anthropologists to think of Christians essentially as those attempting to 'achieve salvation in Christian terms' then their words, values and actions may be considered in relation to this overall aim, even if not every one of these has 'Christian salvation as its proximate goal.' In other words, focusing on 'believe in' statements one should-in a Dumontian perspective-pay attention to the organizing principles or primary ideas or values of the culture in relation to which others are placed, interpreted, and understood. Thus, Robbins is arguing that (Robbins 2007, p. 16) 'believe in' statements rather than 'believe that' ones are more useful for becoming aware of the values organizing a culture, and are the way whereby the notion of belief may be useful for comparative studies in the anthropology of Christianity.

From a different perspective, while foregrounding his own Christian identity in the context of research among the Baguio Baptists in the Philippines, Howell (Howell 2007) makes a related, but in the end quite distinct, suggestion. ${ }^{1}$ Rather than employing belief to see what is comparable across Christian communities, Howell finds that the embodied and relational aspects cannot be separated from doctrinal ones. Beliefs are not merely propositions but the historical, social, institutional 'and bodily context in which "believing" takes place' (Howell 2007, p. 380). Thus, it is the 'contexts' in and through which beliefs are experienced and embraced that need to be ascertained and one has to be quite specific about what point of view in Christianity one is talking about. Indeed, among the Baguio Howell finds a Christianity that is as much a bodily, practiced reality as a matter of 'cognitive assent' (Howell 2007, p. 381). For the Baguio, religious identity is a matter of commitment, which goes beyond belief to include presence and shared practical activity, showing dedication and involvement, engagement and relationality within a shared social space (Howell 2007, p. 378).

It is just at this point then that this literature intersects with the central concerns of this paper. The concept of commitment appears to imagine a cohesiveness of identity of the Baguio Baptists and networks of relations that integrate all into a unit of collective practice. This paper is based on interviews with Catholic Dalits and Dalit activists in the south Indian state of Tamil Nadu, particularly in Chennai and Puducherry, and the representative of the office of Dalit Christians in the Catholic Bishops' Conference of India (New Delhi) as well as non-Dalit Catholics engaged in the struggle for Dalit rights. This paper contends that one finds in this context an absence of such a 'community' and examines the implications of this for belief and commitment among Dalit Catholics. This enables us to interrogate the sharp divide constructed by Robbins between anthropologies of continuity and discontinuity. From an anthropological perspective, community is a highly contested concept. All its prior assumptions of homogeneity, harmonious interaction, shared identity, and moral consensus and, indeed, the positive value associated with its evocation have been critiqued or shown to be inadequate if not altogether fanciful. Anthropologists would much rather focus on contestation, perhaps even conflict, and argue that heterogeneity, hierarchy, and even forms of coercion may characterize communities more than benign connection, cooperation or trust (see, for instance, Brow 1990; Gold 2005; Amit and Rapport 2002; Scott 1976; Tönnies [1887] 2001; Williams 1976). Others write also for instance of the instability and fluidity of communities and the 'viciousness of community-based identity politics' (Pandey 2005, p. 410). In other words, community is no longer an 'unproblematic' concept (Williams 2002, p. 340) within the social sciences. At the same time, it appears difficult to dispense with.

In particular, claims of community continue to be made and to have an appeal. There is an affect and emotion associated with the call of community (Pandey 2005, p. 410). The sense of belongingness and of being a moral collectivity attached to the idea of community make it a powerful symbol. As Pandey argues (Pandey 2005, p. 415) what is 'conjured up' is an idea of the community as an

1 For the purposes of this paper, the dialogue between Robbins and Howell is both useful and sufficient to lay the ground for the notion of community that I wish to foreground here. However, it must be acknowledged that there are many views on this question of belief in the context of Christianity including for instance Kirsch's (Kirsch 2004) articulation of the unstable and cyclical nature of believing dependent on its performative power or Tooker's idea of belief not being an internal condition of assent (Tooker 1992). See also (Engelke 2002). 
entity as 'natural' and based on 'deep-rooted' bonds as the family with 'clear notions of the members' moral/ethical norms and responsibilities.' Anthropologists are familiar with political projects (Pandey 2005 , p. 410) of this kind wherein entities such as the nation, tribe or religious group may be invoked as communities with memories, histories, collective experiences, and pasts which bind them and give credence to these claims. What this paper identifies is a different struggle wherein Dalit Catholics require of the church that it be true to its self-identification as a community.

\section{Caste in the Tamil Catholic Church}

There are stark divisions of caste that manifest themselves in the Tamil Catholic church in almost all aspects of religious life: space allocations in church and cemetery, performance of rites and ceremonies, and even access to clerical services. Such divides exist both within and outside of the church. A young research scholar and activist $B$ said:

[I]n my mother's village, still Dalits cannot lift and carry the chariot of Mother Mary during festivals ... In the 1840s, the ancestors of my mother converted to Christianity. Nearly 170 years have passed but they are unable to change the caste system ... In the places where the domination of Vanniyars are more, Paraiyar communities still cannot enter the churches. Because of this, there was a riot in Erayur in Villupuram district nearly six years ago and many people died in police firing. In that village, they do not pull the chariot of Mother Mary. Instead they lift and carry the chariot. Under this practice, Vanniyars alone carry it and so they carry it only to the places where their community lives. So, Dalits who live in considerable number there demanded that the chariot be carried to their streets too. The protest turned violent and the church got closed. Then the problem was solved by having separate churches for each caste. (Interview in June 2017, Chennai)

As he reiterated, the priests prefer separation on caste lines over attempting to create harmony within the community. Rather than work towards an enhancement of integration, the clergy effectively collude in limiting the sense of community to boundaries drawn by caste. In a context of dominant versus subordinate castes as in the Tamil countryside, this is particularly pejorative for the latter. There were many accounts of discrimination in appointments to the clergy but also to relatively low-level positions in lay parish associations and the like. Dominant castes are over-represented at all levels in the clerical hierarchy and occupy most positions of decision-making. ${ }^{2}$

On the whole, Dalits are very poorly represented in the clergy and caste Christians are effectively in control of all decision-making positions. This has consequences outside of the spiritual domain. Dalits are often not able to afford the fees of Catholic-run schools and colleges, they remain outside of the power structures of these institutions and experience discrimination when it comes to employment in them. Several individuals narrated how they were subtly discouraged from entering the seminary and others spoke of being denied college admission or being dissuaded from applying. Some of those who overcame both caste and economic disadvantage to enter higher education institutions and complete their degrees could not do so without the explicit support and help of particular priests or individuals sympathetic to the Dalit cause. Such psychological or economic support is however not routinely offered by institutions.

Dalit representation in the clergy has been an important issue for the Dalit Christian Liberation Movement (DCLM) in Tamil Nadu. For Fr Yesumarian, a Dalit Catholic activist and Jesuit, citizenship is a contradiction for the Dalit '[b]ecause there is no full citizenship.' According to him, there is 'the structural system that prevails, that discriminates. The structuralized system excludes me.' $\mathrm{Fr}$ Yesumarian was instrumental in the formation of the Chengalpattu diocese for Dalits, which came

2 This is corroborated by Fr Yesumarian. According to him, when DCYM merged with DCLM in the early 1990 s, over $70 \%$ of the Tamil Catholics were Dalits. However, there was not even one Dalit bishop. At present, four out of 18 bishops are Dalits. 
after a great deal of struggle in the church. Jesuits also oppose him for advocating the cause of Dalits and he is reproached for causing discord and divisions and damaging the reputation of the church. The experience of being simultaneously Dalit and Christian is painful to him. As he says, the 'Jesuit community in Tamil Nadu is predominantly caste minded'. Hostility and resentment is communicated, even if not overtly.

'[B]eing a Dalit in this country is a pain. That is why Ambedkar said, 'I wish I had been consumed in my mother's womb rather than being born an untouchable in this country'. Because you are a Dalit, all your qualities, the church, the society they treat you, it is embedded feeling, that is why the struggle has to be very hard, constant and consistent. In this country, religion is like a shirt, caste is like skin. You can change your shirt but your skin remains.'

The church has impleaded itself in the Dalit Catholics' legal struggle against the Indian state, which denies non-Hindu Dalits from access to reservations in public services and in education. ${ }^{3}$ At the same time, Fr Yesumarian takes a different view, pointing out that the church itself practices discrimination under refuge of the 'minority rights' provisions of the Indian constitution. According to him:

You should have seen the speech of Pope Francis in Myanmar on 29th of November [2017]. He says to the bishops, 'My brothers, go to the fields and villages to bear the smell of the sheep like a shepherd. And don't remain in the confines of the churches. As a Dalit, I understand immediately. In villages, they say Dalit smelling, ugly, that is what they say no? What he says that the bishops are shepherds, first he said, you should smell your sheep. Now he says bear the smell. That means your skin has become their skin. That is the church, with the people. We are very far away from the kingdom of God. Minority rights we spoke in the context of independence of India. After independence, they thought minorities will not have safety and security. And the other intention is the minority institutions are supposed to educate, empower and prepare their own minority people. But what the minority institutions are doing today?

Thus, Dalit members of the church do not experience Christian equality or any sense of fraternity or community. On the other hand, they come up against structural inequalities in the church which prevail against them. In fact, even the constitutional right (Article 30) guaranteed to minorities to run educational institutions for their own betterment works in a way that excludes Dalit Catholics. Article 30 includes a cluster of rights of decision-making and administrative control in minority educational institutions as well as with regard to land, financial resources, and employment therein. Elite caste Catholics are effectively the main bearers of these rights, given the positions they hold within the power structures of these institutions. Apart from schools and colleges, there are Catholic orphanages, old age homes, hospices and hospitals, and other such facilities. Dalits' claims against the state are backed by the church. However, there are no systematic policies of reservation in their own institutions-with regard to either education or employment-for those from disadvantaged and deprived backgrounds. As a result, the Catholic community remains divided and Dalits experience discrimination and inequality in representation in the clergy, in power structures, and in access to the church or institutions run by it. At the same time, the church in Tamil Nadu in particular has relied considerably on its large Dalit membership to lead the struggle against any state attempts to dilute the provisions of Article 25 of the constitution including its controversial clause regarding the right to propagate religion. It was Dalit Christian protests that were in part responsible for the state backtracking in 2004 on a bill banning conversions. One may further discuss the ritual life of the church,

3 This is the basis of the plaintiffs' argument in WP 180/04 filed in the Supreme Court of India. 
its spaces, religious services, and ceremonies. While the literature (for example, Bayly 1989; Wiebe and John-Peter 1977; Anderson 2013) has shown a great deal of evidence of caste struggles within the church and its processions or cemetery spaces, even today one finds dual cemeteries in certain parts of rural Tamil Nadu: one for Dalits and the other for caste Catholics. Processions circumvent the Dalit wards of the village. As a young Catholic in Chennai said: 'A high caste family will hesitate to participate a family prayer conducted by a Dalit family. And communion service in those days were not same like today. Today we distribute wine in separate mini glasses. But in those days, wine would be served in the same cup and high caste people were not comfortable in sharing the same vessel and so the method was changed. But still discrimination exists in the heart of the people in church.'

Again, a Catholic civil engineer talked of how 'in some churches, the dead body of a Dalit is not allowed to be taken inside for rituals while the dead body of other castes is allowed. Also, while selecting the committee members for the church, we are almost not given chances for participation. Otherwise, the members would be grouped together as Dalit on the one hand and all other castes on the other hand. This would never bring God's blessings either to the church or to the people.' Another Dalit Catholic activist spoke of the fact that 'there were also separate vehicles for carrying the dead bodies of upper castes and the Dalits. Dead bodies of Dalits could not be carried through the common path. They must be taken through the path at the back side of the village. The burial grounds were also different. These customs are still in practice.' There have been raging conflicts over these issues in many parishes. In some cases, legal battles have also ensued. Usually one finds as a result of these struggles that if they are not able to keep out the Dalits, caste Catholics will withdraw from church celebrations or processions. Alternatively, a decision may be taken to divide the congregation and create a new church or chapel for the Dalits, legitimating a policy of separation in religious matters. ${ }^{4}$

Discrimination within the church or its educational and welfare institutions is not all. For my informants, the denial of spiritual services or representation in the church are not the only forms of disadvantage they experience. There are further areas of Catholic social life in which invidious forms of distinction manifest themselves and subtle ways are found to communicate the inferiority and undesirability of others. There is a wider sense of being excluded. It is in everyday social intercourse that Dalits experience rudeness, incivility, and social distance. The more recent scholarship on the phenomenological understanding of caste in terms of humiliation specifically seeks to encapsulate the emotional weight of feeling repulsed and being unwelcome. ${ }^{5}$ It is precisely these ideas that enable the uncovering of covert ways in which Dalits are dishonored even as Catholics may not openly admit to the recognition of caste.

While commensality across the caste divide has now become a part of social life, especially in cities, an area with highly resistant barriers is marriage. Even today inter-caste marriage is rare. An elderly Dalit Catholic J said:

Especially, when grown up sons and daughters are there ... the Dalits are blindly neglected from such topics. The moment when you understand that you are not needed/expected to be there, it embarrasses us why such identity is still associated with us even after we converted to Christianity. Sometimes, we understand the foolishness and simply let it go. But after a point the feeling of being neglected or unwanted is really disturbing. In Bible, as far as I know ... Jesus never belonged to any such group ... He taught us to be holy. Holiness doesn't require these caste identities. (Interview in March 2017, Chennai)

In such situations, Dalits are left feeling excluded and embarrassed just by the fact of their presence. As a middle-aged informant said:

4 Fr Yesumarian, interview in Chengalpattu, December 2017. For details on recent battles over churches, cemeteries, and processions see also (Dorairaj 2011).

5 See, for instance, (Guru 2011) and (Guru and Sarukkai 2012). One may also see (Murugan and Lakshmi 2018); (Gidla 2017) and (Bama 2014). 
We never wanted to carry this identity inside Christianity ... Honestly, I cannot engage in alliance discussion with the common public in the church. Though I try, somehow I will be guided to another Dalit Christian for such practices. You [the Dalits] may forget the differences and try to mingle with others but they [the high caste] will always remind you about your identity and fix you there. No problem in attending marriages etc. but not in making alliances. Then the barrier reinserts itself. Hence, we are expected to understand that we are under the margin and certain people—-high caste—are always socially high in the ladder. (Interview in March 2017, Chennai)

Dalits are made to feel unwanted by means that are unobtrusive though not unclear. There is a shrewd way of drawing the boundaries of inclusion and keeping the Dalit out in such a manner that he or she is unable to actually articulate or point to any specific act or word of discrimination. This in itself is both an indicator of the power of the elites to convey a message without having to say anything explicit and the defenselessness of the Dalit exposed to such humiliation with no means to either pinpoint or thwart it.

From the pulpit or outside the church, priests do not engage with or even mention the caste issue. In fact, as mentioned earlier, this is considered a divisive subject which brings down the image of the church. A safe and neutral position is adopted by neither speaking for or against caste discrimination. At best, the priests make a general reference to the unity of the Catholic community and speak in abstract and lofty terms, without addressing directly or specifically the obvious manifestations of caste separation and discrimination that confront them in their congregations. As J said:

Priests rarely speak on caste related issues in their sermons. They speak on unification of Christians, togetherness, tolerance, fraternity, affinity, etc. But there is another side called as 'discrimination' ... They never speak on this area. Most of the time they play a safe role-they never speak for or against discrimination inside the church ... This is one of the reasons caste still plays a vital role among Christians. And this leads to all kinds of discrimination inside the church.

Thus, a silence is drawn over the issue of caste and even a mention of it is evaded because it would harm the church's standing in society. On the other hand, what is stressed is togetherness, a spirit of harmony, tolerance, and fraternity. These are all sentiments associated with 'community' as it were, but for Dalits it appears that the church merely uses these terms rhetorically or at best in reference to some other-worldly spiritual union while real, existing inequalities and rifts remain unacknowledged. ${ }^{6}$ While Dalits believe in the promise of equality and redemption of the Bible and that preached in the church, they constantly come up against a different social reality in everyday life. Another Dalit activist in the church said: 'It is not true that some human beings are by nature superior and some others inferior. All men are equal because everyone has natural dignity. Since all men ... are created in God's likeness, they have the same nature and origin [and] have been redeemed by Christ ... basic equality of all must receive increasingly greater recognition.'

\section{Belief, Commitment, Community}

Let me return to the concerns with which this paper started. Catholic Dalits believe in Jesus as a redeemer and revolutionary. I spoke earlier of the lay Catholic J who said 'Jesus never belonged to any such group. Rather, he was a revolutionary, he was against his own identity, calling himself as a Jew. He taught us to be holy. Holiness doesn't require these caste identities. However, there are priests who still carry the tags of their caste with their names.' Fr Yesumarian was inspired at a young age to

6 Not unexpectedly, Dalit theological movements gained momentum in Tamil Nadu. However, the overall marginalization of the Dalit Christians emphasizes the inability or the refusal of the church to come to terms with caste discrimination either socially or theologically. 
become a priest and work for the liberation of Dalits. When he was not permitted to join the diocesan seminary, he became a Jesuit. He believes deeply in Christian values. Both Jeremiah 1: 4-12 and Luke 4: 18-19 which he selected as readings for his first mass are at the core of his beliefs.

Jeremiah 1: 4-12 begins with a personal encounter and call to the prophet; it includes God's personal touch communicated to the prophet in his vision and holds out the promise of a worldwide ministry. ${ }^{7}$ According to Luke 4: 18-19, The Spirit of the Lord is upon me, because he has anointed me to preach good news to the poor. He has sent me to proclaim release to the captives and recovering of sight to the blind, to set at liberty those who are oppressed, to proclaim the acceptable year of the Lord.' The verses bear the vision of justice and faith and liberation from oppression for the poor that brought Fr Yesumarian into the fold of the Jesuits. What emerges further is that Dalits believe that they are created in the image of Christ and in his likeness, even as they experience agonizing forms of actual discrimination. In other words, in contradiction to the assumptions of the new anthropology of Christianity, continuity in terms of preserving caste privilege is neither a product of the anthropologist's effort 'to make Christianity largely disappear from the story' (Robbins 2007, p. 8) nor is it a matter of choice for the Dalits themselves. Continuity is both real and thrust on the Dalits by those who seek to keep them out. One recollects J's assertion that it embarrasses Dalits that they are associated with an identity they considered they had left behind on conversion to Christianity. Thus, while beliefs in may be useful to understand Christianity from a comparative viewpoint, it may also be pertinent to think about beliefs that, not as conducive to continuity thinking but as a site of struggle and contestation particularly by those resisting the dominant perspective.

One might go further, though, and point out that belief itself as Howell asserts is contextualized and embodied. In Tamil Nadu, clearly 'believing' is understood as being produced through relational processes and conjoint practical activity—'commitment' as it were-because it is surely the imposed separateness of space and of ritual action that causes the excruciating contradiction between caste boundaries and a collective religious identity. This unrelenting marginalization spills into other domains of sociality, particularly that of connubial relations. In other words, what the paper suggests is that the notion of community lurks in the shadow of the idea of commitment. What remains unstated and perhaps taken-for-granted among the Baguio surfaces rudely—precisely because of its denial—in the Tamil context.

It is argued therefore that while the discourse on the anthropology of Christianity oscillates between questions of belief on the one hand and commitment on the other, the intermediating penumbral term between these might be community. The church must be with its people, the Shepherd-Bishop must 'smell' his sheep. The Catholic clergy speak the language of community in terms merely of moral unity and spiritual fraternity which holds little meaning for the Dalit who experiences the bitter humiliations of physical and social separation both within and outside the church. The significant question is not: Is their culture Christian (Robbins 2007, p. 17)? For the Dalits, neither belief nor commitment to the church is absent. What is starkly missing is the shared sense of community that would animate their Christian values and practices. When they find that Christian equality becomes physical separation and Christian fraternity remains outside the social domain, there is an anguished call from Dalits to their church to live up to its professed claims of community. Thus, while community might be anthropologically suspect today, its resonance for those promised while denied must be

$7 \quad{ }^{4}$ Now the word of the Lord came to me saying, ${ }^{5}$ "Before I formed you in the womb I knew you, and before you were born I consecrated you; I appointed you a prophet to the nations." ${ }^{6}$ Then I said, "Ah, Lord God! Behold, I do not know how to speak, for I am only a youth." " 7 But the Lord said to me, "Do not say, 'I am only a youth'; for to all to whom I send you you shall go, and whatever I command you you shall speak. ${ }^{8}$ Be not afraid of them, for I am with you to deliver you, says the Lord." 9 Then the Lord put forth his hand and touched my mouth; and the Lord said to me, "Behold, I have put my words in your mouth. ${ }^{10}$ See, I have set you this day over nations and over kingdoms, to pluck up and to break down, to destroy and to overthrow, to build and to plant." ${ }^{11}$ And the word of the LorD came to me, saying, "Jeremiah, what do you see?" And I said, "I see a rod of almond." 12 Then the Lord said to me, "You have seen well, for I am watching over my word to perform it." 
acknowledged. Moreover, what is revealed is that it is not a continuity-discontinuity opposition or a stress on discontinuities alone that will enable us to comprehend religious and moral change in a complex and highly stratified society of which Christianity is but a part. Through an exploration of the struggle of the Dalits to break caste barriers and claim fellowship in a Christian community, this paper proposes that continuity and discontinuity should not be construed as dichotomous or understood in purely 'cultural' terms a la Robbins (Robbins 2007, p. 17). Rather, they may be thought of as the social and political resources of groups engaged in battles of demonstrating or denying caste privilege and status. In other words, there may yet be a thing or two that the new anthropology of Christianity may retain or learn from the old.

Conflicts of Interest: The authors declare no conflict of interest.

\section{References}

Amit, Vered, and Nigel Rapport. 2002. The Trouble with Community: Anthropological Reflections on Movement, Identity and Collectivity. London: Pluto.

Anderson, H M Jeremiah. 2013. Community and Worldview among. Paraiyars of South India: 'Lived' Religion. London: Bloomsbury Academic.

Bama. 2014. Karukku. Delhi: Oxford University Press.

Bayly, Susan. 1989. Saints, Goddesses and Kings: Muslims and Christians in South Indian Society, 1700-1900. Cambridge: Cambridge University Press.

Béteille, Andre. 1990. Race, caste and gender. Man 25: 489-504. [CrossRef]

Brow, James. 1990. Notes on Community, Hegemony, and the Uses of the Past. Anthropological Quarterly 63: 1-5.

Cannell, Fenella. 2005. The Christianity of anthropology. Journal of the Royal Anthropological Institute 11: 335-56. [CrossRef]

Dorairaj, S. 2011. Caste divide. In Frontline. Chennai: The Hindu, vol. 28, pp. 38-42.

Engelke, Matthew. 2002. The Problem of Belief: Evans-Pritchard and Victor Turner on "the Inner Life". Anthropology Today 18: 3-8. [CrossRef]

Gidla, Sujatha. 2017. Ants among Elephants: An Untouchable Family and the Making of Modern India. New York: Farrar, Straus and Giroux.

Gold, Ann Grodzins. 2005. Conceptualizing Community: Anthropological Reflections a Background Paper for The Collaborative Initiative for Research Ethics in Environmental Health. Available online: https://www.brown.edu/research/research-ethics/sites/brown.edu.research.research-ethics/files/uploads/ Conceptualizing\%20Community\%20-\%20Gold.pdf (accessed on 21 June 2019).

Guru, Gopal. 2011. Humiliation: Claims and Context. Delhi: Oxford University Press, pp. 1-19.

Guru, Gopal, and Sundar Sarukkai. 2012. The Cracked Mirror: An Indian debate on Experience and Theory. Delhi: Oxford University Press.

Howell, Brian. 2007. The repugnant cultural other speaks back: Christian identity as ethnographic 'standpoint'. Anthropological Theory 7: 371-91. [CrossRef]

Jenkins, Timothy. 2012. The Anthropology of Christianity: Situation and Critique. Ethnos 77: 459-76. [CrossRef]

Kirsch, Thomas G. 2004. Restaging the Will to Believe: Religious Pluralism, Anti-Syncretism and the Problem of Belief. American Anthropologist 106: 699-709. [CrossRef]

Murugan, Perumal, and C. S. Lakshmi. 2018. Black Coffee in a Coconut Shell: Caste as Lived Experience. New Delhi: Sage.

Oddie, Geoffrey A., ed. 1977. Religion in South Asia: Religious Conversion and Revival Movements in South Asia in Medieval and Modern Times. Delhi: Manohar Book Service.

Pandey, Gyanendra. 2005. Notions of community: Popular and subaltern. Postcolonial Studies 8: 409-19. [CrossRef]

Robbins, Joel. 2003. What is a Christian? Notes toward an anthropology of Christianity. Religion 33: 191-99. [CrossRef]

Robbins, Joel. 2007. Continuity Thinking and the Problem of Christian Culture: Belief, Time, and the Anthropology of Christianity. Current Anthropology 48: 5-38. [CrossRef]

Robbins, Joel. 2014. The Anthropology of Christianity: Unity, Diversity, New Directions. Current Anthropology 55: S157-S171. [CrossRef] 
Scott, James. 1976. The Moral Economy of the Peasant: Rebellion and Subsistence in Southeast Asia. New Haven and London: Yale University Press.

Tönnies, Ferdinand. 2001. Community and Civil Society. Tr. Jose Harris and Margaret Hollis. Cambridge: Cambridge University Press. First published 1887.

Tooker, Deborah. 1992. Identity Systems of Highland Burma: "Belief", Akha Zan, and a Critique of Interiorized Notions of Ethno-Religious Identity. Man 27: 799-819. [CrossRef]

Wiebe, P. C., and S. John-Peter. 1977. The Catholic church and caste in rural Tamil Nadu. In Caste among Non-Hindus in India. Edited by Harjinder Singh. New Delhi: National Publishing House, pp. 37-49.

Williams, Raymond. 1976. Keywords. London: Fontana Press.

Williams, Brett. 2002. The Concept of Community. Reviews in Anthropology 31: 339-50. [CrossRef]

(C) 2019 by the author. Licensee MDPI, Basel, Switzerland. This article is an open access article distributed under the terms and conditions of the Creative Commons Attribution (CC BY) license (http://creativecommons.org/licenses/by/4.0/). 